\title{
Functional capacity and life expectancy in elderly quilombolas
}

\author{
Capacidade funcional e esperança de vida em idosos quilombolas \\ Capacidad funcional y esperanza de vida en negros cimarrones ancianos
}

Valéria Raissa Oliveira da Silva' ORCID: 0000-0001-8621-2423

Rejane Santos da Cunha" ORCID: 0000-0001-8485-3585

José Luís da Cunha Pena' ORCID: 0000-0002-4705-3025

Ariely Nunes Ferreira de Almeida' ORCID: 0000-0001-5788-6920

Érika Tatiane de Almeida Fernandes Rodrigues' ORCID: 0000-0003-0539-1998

Camila Rodrigues Barbosa Nemer' ORCID: 0000-0003-1252-3709

Veronica Batista Cambraia Favacho' ORCID: 0000-0003-2790-1792

Francineide Pereira da Silva Pena' ORCID: 0000-0001-8465-4252

'Universidade Federal do Amapá. Macapá, Amapá, Brazil. "Secretaria Municipal de Saúde, Unidade Básica de Saúde do Curiaú. Macapá, Amapá, Brazil.

How to cite this article: Silva VRO, Cunha RS, Pena JLC, Almeida ANF, Rodrigues ETAF, Nemer CRB, et al. Functional capacity and life expectancy in elderly quilombolas. Rev Bras Enferm. 2020;73(Suppl 3):e20190531. doi: http://dx.doi org/10.1590/0034-7167-2019-0531

\section{Corresponding author:}

Francineide Pereira da Silva Pena E-mail: fran14pena@gmail.com

EDITOR IN CHIEF: Antonio José De Almeida Filho ASSOCIATE EDITOR: Hugo Fernandes

Submission: 09-30-2019 Approval: 01-17-2020

\section{ABSTRACT}

Objective: To evaluate the relationship between functional capacity and life expectancy of quilombola elders. Method: A quantitative, descriptive, cross-sectional study involving fifty-nine older adults from the quilombola community of Curiaú, Macapá-Amapá. A sociodemographic form was used to characterize the sample, and Lawton's and Herth's Hope Scales were used to measuring functional capacity and life expectancy, respectively. In the relationship study, the Spearman correlation test was applied. Results: Elderly males aged $60-69$ years $(52.5 \%)$ and married (35.6\%) prevailed. Functional capacity had a mean score of $22.4( \pm 4.6)$ and a life expectancy of $41.5( \pm 5.1)$, the correlation between the scale scores was positive and significant $(R=0.475 ; \mathrm{p}<0.001)$. Conclusion: From the results concluded, when related levels of independence and life expectancy among themselves were significantly associated with being functionally independent elderly and having a better life expectancy. Descriptors: Elderly; Functional Capacity; Life Expectancy; Nursing; Group with Ancestors of the African Continent.

\section{RESUMO}

Objetivo: Avaliar a relação entre a capacidade funcional e a esperança de vida de idosos quilombolas. Método: Estudo quantitativo, descritivo, transversal, envolvendo 59 idosos da comunidade quilombola do Curiaú, Macapá (Amapá). Foram utilizados formulário sociodemográfico para caracterização da amostra bem como a Escala de Lawton e a Escala de Esperança de Herth, para mensuração da capacidade funcional e esperança de vida, respectivamente. No estudo de relação, foi aplicado o Teste de Correlação de Spearman. Resultados: Prevaleceram idosos do sexo masculino, entre 60 e 69 anos (52,5\%) e casados $(35,6 \%)$. A capacidade funcional teve escore médio total de $22,4( \pm 4,6)$; e a esperança de vida, de $41,5( \pm 5,1)$; a correlação entre os escores das escalas foi positiva e significativa $(R=0,475 ; p<0,001)$. Conclusão: A partir dos resultados, quando relacionados níveis de independência e esperança de vida entre si, houve associação significativa entre ser idoso funcionalmente independente e ter melhor esperança de vida.

Descritores: Idosos; Capacidade Funcional; Esperança de Vida; Enfermagem; Grupo com Ancestrais do Continente Africano.

\section{RESUMEN}

Objetivo: Evaluar la relación entre la capacidad funcional y la esperanza de vida de negros cimarrones ancianos. Método: Estudio cuantitativo, descriptivo, transversal, envolviendo 59 ancianos de la comunidad de cimarrones de Curiaú, Macapá (Amapá). Han sido utilizados formulario sociodemográfico para caracterización de la muestra bien como la Escala de Lawton y la Escala de Esperanza de Herth, para medición de la capacidad funcional y esperanza de vida, respectivamente. En el estudio de relación, ha sido aplicado el Test de Correlación Spearman. Resultados: Prevalecieron ancianos del sexo masculino, entre 60 y 69 años (52,5\%) y casados $(35,6 \%)$. La capacidad funcional tuvo escore medio total de $22,4( \pm 4,6)$; y la esperanza de vida, de $41,5( \pm 5,1)$; la correlação entre los escores de las escalas han sido positiva y significativa ( $R$ $=0,475 ; p<0,001)$. Conclusión: A partir de los resultados, cuando relacionados niveles de independencia y esperanza de vida entre sí, hubo asociación significativa entre ser anciano funcionalmente independiente y tener mejor esperanza de vida.

Descriptores: Ancianos; Capacidad Funcional; Esperanza de Vida; Enfermaría; Equipos con Ancestrales del Continente Africano. 


\section{INTRODUCTION}

The significant increase in the elderly population has been associated with the combination of several factors, among which the following stand out: the reduction in mortality rates and advances in medicine ${ }^{(1)}$. However, aging is a dynamic, progressive process that culminates in constant changes, which can have negative consequences on functional capacity, with an increase in the number of dependencies. Consequently, there is a decrease in the level of physical activity and an increase in the number of chronic non-communicable diseases ${ }^{(2)}$.

With this in mind, it is appropriate to feed life expectancy whenever there is an imbalance or functional performance, as hope affects the health/disease process positively, helping the elderly to face uncertainties of the future in a more dynamic way and with satisfactory results(3).

Life expectancy is considered a constitutive element of human existence in time, as it is what sustains the opening to the future of the being that we are. All clinical work is supported and driven by hope. Therefore, therapeutic consequences are disastrous when dealing with hopelessness. For the elderly, it leaves them vulnerable to the emergence of health problems $s^{(2,4)}$.

Therefore, in the face of aging, some critical challenges arise, among them the preservation of functional capacity, which is the main parameter for assessing the health and quality of life of the elderly ${ }^{(5)}$. The assessment of functional capacity in health practices is essential for choosing the type of intervention and monitoring the clinical and functional status of the elderly ${ }^{(6)}$. In this sense, health-promoting and disease-prevention measures aim at maintaining functional capacity and preventing disabilities, along with adequate management of existing comorbidities ${ }^{(5)}$.

In turn, investigating life expectancy in the elderly is also necessary as it is understood as a feeling that moves human beings to believe in positive results. There are, in hope, traces of perseverance, because people can believe that something is possible even when there is evidence to the contrary ${ }^{(7)}$. Therefore, the presence or absence of this feeling in older adults is essential for coping with the aging process and their perception of commitment to health.

However, studies that address the discussion of these two aspects - functional capacity and life expectancy in the elderly - are still incipient, and even more rare are those that target the rural or quilombola elderly population. In Brazil, most works address the elderly population in an urban area, in large capital cities ${ }^{(8)}$.

All these facts considered, the present study justifies itself by the need to assess the functional capacity of quilombola older adults as well as to correlate it with life expectancy, to provide adequate and consistent assistance with their needs. The knowledge derived from the results can serve as subsidies for systematizing care, planning strategies, and interventions appropriate to the local reality of the elderly. This knowledge is important because disability problems are frequent in the elderly population.

In this context, observing the value of functional capacity as an indicator of health and quality of life, as well as life expectancy as an existential dimension with significant meaning in the daily lives of older adults, the following research question emerged: What is the relationship between functionality and life expectancy of quilombola older adults in the Environmental Protection Area of Curiaú?

\section{OBJECTIVE}

To evaluate the relationship between functional capacity and life expectancy of quilombola elderly residents in the Environmental Protection Area (EPA) of Curiaú, in the state of Amapá, as well as presenting characteristics of the elderly related to social, economic and demographic variables.

\section{METHODS}

\section{Ethical aspects}

This study was submitted to the Research Ethics Committee of the Universidade Federal do Amapá (Federal University of Amapá-UNIFAP). Once approved, the study complied with all the principles and rules pre-established by Resolution 466/2012 of the Conselho Nacional de Saúde (National Health Council), which regulates research with human beings.

\section{Design, place and period}

A cross-sectional, descriptive study with a quantitative approach, guided by the STROBE tool and carried out in the quilombos community of Curiaú. The research scenario is the Environmental Protection Area (EPA) of the Curiaú River, in the municipality of Macapá, Amapá, Brazil. Data collection took place between August and October 2017.

\section{Population and sample: inclusion and exclusion criteria}

The study population consisted of 59 older adults, of both genders, aged over 60 years. The sample was non-probabilistic, of convenience and accessibility type, recruited in 2017. The inclusion criterion took into account the elderly registered in the Estratégia Saúde da Família (Family Health Strategy), team 062, residents of the community researched, in the area of Curiaú de Dentro (Inside Curiaú) and Curiaú de Fora (Outside Curiaú). The study excluded those diagnosed with cognitive impairment or hearing impairment.

\section{Study Protocol}

We approached the participants and guided them about the research objectives, pointed out the benefits and harms, read the Free and Informed Consent Form (FICF), requesting their signature.

Data collection used: 1) sample characterization form, composed of closed questions related to social, economic and demographic variables; 2 ) Lawton scale (LS) for assessing the degree of dependence of the elderly in relation to Instrumental Activities of Daily Living IADLs ${ }^{(9)}$ and; (3) Herth Hope Scale (HHS), validated in Brazil in $2008^{(10)}$. LS assesses elders'ability to adapt to the environment in which they live and covers various activities such as using the phone, shopping, preparing meals, cleaning the house, washing clothes, taking care of the garden, using transportation, climbing stairs, taking medicine, taking care of the budget. It consists of nine statements that assess independence in carrying out the activities described above, with a 3-point Likert scale response ( $1=$ cannot do it, $2=$ with partial help, and $3=$ without help), whose total score is 9 to 27 points ${ }^{(9)}$. HHS, on the other hand, seeks to assess the multidimensionality of hope. It 
consists of 12 statements with a 4-point Likert scale response $(1=$ strongly disagree; 2 = disagree; 3 = agree; and 4 = strongly agree), whose total score is 12 to 48 points ${ }^{(10)}$.

The elderly received the self-applied instruments during home visits, respond ed to it voluntarily. The researchers read the instruments for those who had reading difficulties, adapting the interviewees' language, as allowed by the scales ${ }^{(9-10)}$.

\section{Results analysis and statistics}

The descriptive analysis used the program Statistical Package for the Social Sciences (SPSS), version 22, for Windows 13. We used for quantitative variables, the mean and standard deviation (SD), and, for the categorical ones, the absolute (n) and relative (\%) frequencies. Cronbach's Alpha value determined the reliability of the LS and HHS scales, and the recommended value was higher than 0.70 , and the accepted values above $0.60^{(11)}$.

The $95 \%$ index defined the confidence level. For the decision regarding the statistical significance of the results, we considered a level of $5 \%$, that is, the differences or correlations were considered statistically significant if the significance value was lower than $0.05(p<0.05)$.

We used the Kolmogorov-Smirnov test to evaluate the normality of the data. The results $(p<0.05)$ led to the conclusion that none of the variables under study had a normal distribution. Finally, we decided to use parametric tests to respond to the research objectives: Mann-Whitney test - comparison of quantitative variables (HHS and LS scores) between two independent groups; Kruskal-Wallis test - comparison of quantitative variables (HHS and LS scores) between three or more independent groups; and Spearman's Correlation Coefficient - correlation between at least ordinal variables.

\section{RESULTS}

Were recruited 59 quilombola older adults, $52.5 \%$ of whom were men, aged between 60 and 99 years old, with an average of 70.6 ( \pm 9.1 ) years. Regarding marital status, married people predominated (35.6\%). For the variable "schooling," the majority studied between 1 and 3 years (44.1\%). Most have a family income of 1 to 3 minimum wages (93.2\%) and belong to the Catholic religion (96.6\%). About 4 out of 5 (79.7\%) live with family members, and only $20.3 \%$ live alone. As for pathologies, $83.1 \%$ deny having diabetes mellitus (DM), 47.5\% have systemic arterial hypertension $(\mathrm{SAH})$, and $52.5 \%$ do not have $\mathrm{SAH}$. Regarding the race/color variable, $91.5 \%$ declared themselves black; $1.7 \%$, white; $5.1 \%$, pardos (brown); and 1.7\%, yellow (Asiatic descendants) (Table 1).

For the assessment of the degree of dependence of the elderly concerning Instrumental Activities of Daily Living - older adults evaluated by the Lawton Scale (LS) - 70\% had significant levels of independence, with the highest scores values. As shown in Table 2, the first item is about the use of cell phones, with the activity having the most significant percentage among the participants $-40.7 \%$ answered that they were unable to use it, and $5.1 \%$ said that they could use the phone without help. In item 8 , which is about taking medication, only $6.8 \%$ are unable to take their medication at the correct dose and time, with $22 \%$ doing it with partial help, and $71.2 \%$ without help.
Most participants can carry out activities without help (60\%) on all items, except for the use of the telephone. The value of Cronbach's Alpha of LS was 0.88 , indicating that the scale has significant levels of reliability.

The analysis of the level of independence assessed by the LS score showed significant values of $22.4 \pm 4.6$ of the mean, 24 of the median, and K-S Test $p<0.001$. The elderly are more independent in the sample studied.

Considering the assessment of older adults'life expectancy, with the Herth Scale, relevant levels of life expectancy were obtained, about $70 \%$ of the elderly had scored higher values (equal to or higher than 41). As for the reliability of HHS, using Cronbach's Alpha, after the inversion of the scores of items 3 and 6 , a value of $a=0.71$ was obtained; good reliability of the scale, when all statements are analyzed.

Finally, the elderly who responded more often that they agreed with the statements of the HHS scale are more likely to have a higher life expectancy, except for items 3 and 6, which present an opposite way in relation to the others (Table 3 ).

Regarding the analysis of the level of life expectancy using the HHS score, the study evidenced significant values of the mean $(41.5 \pm 5.1)$, median (43), and K-S test $(p<0.001)$. These results were significantly associated with relative levels of life expectancy in this population.Quilombola older adults with a higher degree of independence correlated more significantly with those with higher life expectancy, according to the correlation coefficient by Spearman between the LS and HHS scores $(R=0.475 ; p<0.001)$ (Figure 1).

Table 1 - Demographic, social, economic, and pathological characterization of older adults in the quilombola community of Curiaú. Macapá, Amapá, Brazil, $2018(\mathrm{~N}=59)$

\begin{tabular}{|c|c|c|c|}
\hline Variables & & $\mathbf{n}$ & $\%$ \\
\hline Gender & $\begin{array}{l}\text { Male } \\
\text { Female }\end{array}$ & $\begin{array}{l}31 \\
28\end{array}$ & $\begin{array}{l}52.5 \\
47.5\end{array}$ \\
\hline $\begin{array}{l}\text { Age } \\
\text { Minimum }=60 \\
\text { Maximum }=99 \\
\text { Mean }(S D)=70.6(9.1)\end{array}$ & $\begin{array}{l}60 \text { to } 69 \text { years old } \\
70 \text { to } 79 \text { years old } \\
80 \text { to } 89 \text { years old } \\
90 \text { to } 99 \text { years old }\end{array}$ & $\begin{array}{c}31 \\
15 \\
12 \\
1\end{array}$ & $\begin{array}{c}52.5 \\
25.4 \\
20.3 \\
1.8\end{array}$ \\
\hline Marital Status & $\begin{array}{l}\text { Single } \\
\text { Married } \\
\text { Divorced } \\
\text { Stable Union } \\
\text { Widower }\end{array}$ & $\begin{array}{c}8 \\
21 \\
2 \\
13 \\
15\end{array}$ & $\begin{array}{c}13.6 \\
35.6 \\
3.4 \\
22.0 \\
25.4\end{array}$ \\
\hline Schooling & $\begin{array}{l}\text { None } \\
1 \text { to } 3 \text { years } \\
4 \text { to } 7 \text { years } \\
8 \text { years or more }\end{array}$ & $\begin{array}{c}8 \\
26 \\
22 \\
3\end{array}$ & $\begin{array}{c}13.6 \\
44.0 \\
37.3 \\
5.1\end{array}$ \\
\hline Family Income & $\begin{array}{l}<1 \text { minimum wage } \\
1 \text { to } 3 \text { minimum wages } \\
4 \text { to } 6 \text { minimum wages }\end{array}$ & $\begin{array}{c}2 \\
55 \\
2\end{array}$ & $\begin{array}{c}3.4 \\
93.2 \\
3.4\end{array}$ \\
\hline Religion & $\begin{array}{l}\text { Catholicism } \\
\text { Evangelicalism }\end{array}$ & $\begin{array}{c}57 \\
2\end{array}$ & $\begin{array}{c}96.6 \\
3.4\end{array}$ \\
\hline Lives with family & $\begin{array}{l}\text { No } \\
\text { Yes }\end{array}$ & $\begin{array}{l}12 \\
47\end{array}$ & $\begin{array}{l}20.3 \\
79.7\end{array}$ \\
\hline Diabetes Mellitus & $\begin{array}{l}\text { No } \\
\text { Yes }\end{array}$ & $\begin{array}{l}49 \\
10\end{array}$ & $\begin{array}{l}83.1 \\
16.9\end{array}$ \\
\hline Systemic Arterial Hypertension & $\begin{array}{l}\text { No } \\
\text { Yes }\end{array}$ & $\begin{array}{l}31 \\
28\end{array}$ & $\begin{array}{l}52.5 \\
47.5\end{array}$ \\
\hline
\end{tabular}


Table 2 - Functional capacity in elderly quilombolas in the community of Curiaú by item of the Lawton Scale, Macapá, Amapá, Brazil, 2018 (N = 59)

\begin{tabular}{|c|c|c|c|}
\hline Lawton Scale & $\begin{array}{c}\text { Unable } \\
\%\end{array}$ & $\begin{array}{c}\text { Do it with } \\
\text { partial help } \\
\%\end{array}$ & $\begin{array}{c}\text { Can do it } \\
\text { without help } \\
\%\end{array}$ \\
\hline 1. Can you use the phone? & 40.7 & 54.2 & 5.1 \\
\hline 2. Can you go to distant places, using transportation, without the need for special planning? & 11.9 & 20.3 & 67.8 \\
\hline 3. Can you go shopping? & 16.9 & 10.2 & 72.9 \\
\hline 4. Can you prepare your meals? & 13.6 & 1.7 & 84.7 \\
\hline 5. Can you clean up the house? & 16.9 & 5.1 & 78.0 \\
\hline 6. Can you do household work, such as minor repairs? & 16.9 & 11.9 & 71.2 \\
\hline 7. Can you wash and iron your clothes? & 18.6 & 16.9 & 64.4 \\
\hline 8. Can you take your medication at the correct dose and time? & 6.8 & 22.0 & 71.2 \\
\hline 9. Can you take care of your finances? & 11.9 & 13.6 & 74.6 \\
\hline
\end{tabular}

Source: Lawton scale(9).

Table 3 - Life expectancy in elderly quilombolas in the community of Curiaú by item of the Herth Hope Scale, Macapá, Amapá, Brazil, 2018 (N = 59)

\begin{tabular}{lcccc}
\hline Herth Hope Scale & $\begin{array}{c}\text { Completely disagree } \\
\%\end{array}$ & $\begin{array}{c}\text { Disagree } \\
\%\end{array}$ & $\begin{array}{c}\text { Agree } \\
\%\end{array}$ & $\begin{array}{c}\text { Strongly Agree } \\
\%\end{array}$ \\
\hline 1. I'm optimistic about life & 8.5 & 6.8 & 11.9 & 72.8 \\
2. I have short and long term plans & 28.8 & 11.9 & 32.2 & 27.1 \\
3. I feel very alone & 57.6 & 8.5 & 15.3 & 18.6 \\
4. I can see possibilities amid difficulties & 10.1 & 15.3 & 40.7 & 33.9 \\
5.I have a faith that comforts me & $1.7 \%$ & $1.7 \%$ & 8.5 & 88.1 \\
6. I'm afraid of my future & 76.2 & 11.9 & 5.1 & 6.8 \\
7.I can remember happy and pleasant times & 8.5 & 6.1 & 6.8 & 79.6 \\
8. I feel strong & 5.1 & 0.0 & 13.6 & 74.5 \\
9. I feel capable of giving and receiving affection/love & 1.7 & 10.2 & 15.3 & 84.7 \\
10.I know where I want to go & 11.9 & 0.0 & 15.3 & 62.6 \\
11.I believe in the value of each day & 0.0 & 0.0 & 8.5 & 84.7 \\
12.I feel that my life has value and utility & 0.0 & & & 91.5 \\
\hline
\end{tabular}

Source: Herth Hope scale ${ }^{(10)}$

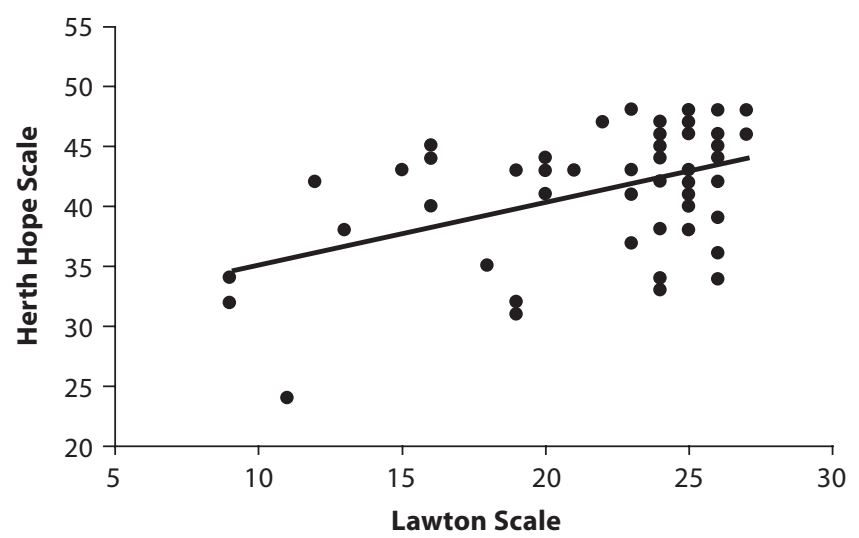

Figure 1 - Scatter diagram of the scores of the Lawton Scale and the Herth Hope Scale

\section{DISCUSSION}

It is essential to highlight the predominance of older adults with levels of independence deserves, since the data with the highest number among non-dependent older adults (70\%), according to the Lawton Scale categorization, corroborate the literature. The research carried out by Berlezi et al. ${ }^{(8)}$ points out that most of the elderly are able to perform their instrumental activities of daily living (83.7\%), confirming the findings of this study.

The variable "residents with family members" was predominant among the elderly in this sample, with most respondents having less possibility of dependence to develop instrumental activities of daily living (LS). In contrast, in the study by Barbosa et al., the category "without a partner" showed a higher possibility of dependence on basic activities of daily living ${ }^{(12)}$.

The results of this study indicated that the quilombola elderly had an average LS equivalent to the high degree of functional independence, in agreement with the study carried out in the city of Montes Claros (MG) ${ }^{(12)}$. However, these results are different from those obtained in other studies, which found variation between (64.4\% to $72.2 \%$ ) the elderly evaluated, considered dependent on IADLs ${ }^{(13-15)}$. The assessment of functional capacity is essential to determine the commitment and the need for assistance for the activities of maintenance and promotion of one's health, including the management of the home environment by the elderly, whether quilombola or not ${ }^{(16)}$.

This study found higher levels of life expectancy (HHS) in the quilombola elderly. This finding coincides with the results found in the HHS translation and validation study with people with DM, companions, and people with oncological diseases, in which the mean score was, respectively, 40.46, 40.88 and $41.25^{(13)}$.

However, the results obtained in our study showed averages in life expectancy (HHS) above studies carried out with older adults with chronic kidney disease, in which the average life expectancy was $36.20^{(17)}$ and, among the elderly in Vitória (ES), it was $35.88^{(2)}$.

In previous studies ${ }^{(1-7)}$ with older women, the average found for life expectancy was 38.1 and 34.86, respectively. Both had a lower average life expectancy compared to elderly quilombolas participating in our study.

In addition to life expectancy, older adults with diagnosed chronic diseases (82.6\%) showed lower average life expectancy scores $(35.88)^{(2)}$. We found results that corroborate this hypothesis: 
the percentage of older adults who responded to having SAH was $47.5 \%$, and the life expectancy score was 41.5 . Therefore, the fewer diagnoses of morbidities, the higher the life expectancy. These results infer that the clinical characteristics of the quilombola elderly population are different from those present in the studies mentioned above since the elderly had diseases that greatly influence their life expectancy. It was found that the elderly with DM and SAH have a good perception of their health, converging to an appropriate follow-up performed by the ESF since they have adequate control of diseases.

In the present study, the functionality and life expectancy of the elderly in the Curiaú quilombo show a direct correlation between the two scales, that is, the elderly who are more independent to develop their activities have more life expectancy. This finding is probably possible because of the older adults' health conditions, because the better their perception of health, the higher their perspective on the future, even with the limitations imposed by aging. Functional autonomy is closely related to psychological well-being and is considered an essential condition for successful aging ${ }^{(18)}$.

\section{Study Limitations}

As study limitations, the small number of older adults in the surveyed area (quilombos) stands out. As the data originated from a sample for convenience and not probabilistic, they leave weaknesses in the results. However, they do not invalidate them.

\section{Contributions to nursing}

This study was the first one conducted in the healthcare field of quilombola elderly - in this case, residents in an area of environmental protection in the northern region of the country that assesses and correlates functional capacity and life expectancy, contributing to a reflection on the care needs of nursing services for quilombola elderly. The results demonstrate the importance of identifying and implementing care in primary health care based on practices that can help improve care, directly impacting the quality of life of this population.

\section{CONCLUSION}

The results showed that elderly quilombolas showed high levels of functional independence, with difficulty only concerning the use of the cell phone. Life expectancy, and its respective levels, was also satisfactory. When levels of independence and life expectancy were related to each other, there was a significant association between being functionally independent elderly and having a better life expectancy.

Evaluating the relationship between the functional capacity and life expectancy of elderly quilombolas, as well as presenting their characteristics related to social, economic, and demographic variables, made it possible to understand these two essential constructs for assessing the health of the elderly. Also, we found that it is important to consider the functional capacity and life expectancy of elderly quilombolas for the construction of prevention strategies as a way to ensure as much as possible the independence and autonomy of the elderly. It is essential to highlight the quality of life of this population in public policies, especially those related to the black population, with an emphasis on care in primary health care for the elderly to promote health and prevent diseases.

\section{REFERENCES}

1. Fonseca PN, Dantas Ge, Coelho GLH, Carvalho TA, Pontes AM. Esperança em idosos: uma explicação baseada nos valores humanos. Estud Interdiscipl Envelhec [Internet]. 2015 [cited 2019 May 20];20(1):9-25. Available from: https://seer.ufrgs.br/RevEnvelhecer/article/view/48522/34918

2. Oliveira LM, Silva SM, Lima EFA, Gomes MGC, Olympio PCAP. The life hope of elderly: profile assessment and Herth Scale. Rev Pesqui: Cuid Fundam. 2018;10(1):167-72. doi: 10.9789/2175-5361.2018.v10i1.167-172

3. Pinto S, Caldeira S, Martins JC. A esperança da pessoa com cancro - estudo em contexto de quimioterapia. Rev Enferm Ref. 2012;7(III):23-31. doi: $10.12707 /$ RIII11148

4. Rocha Z. Esperança não é esperar, é caminhar: reflexões filosóficas sobre a esperança e suas ressonâncias na teoria e clínica psicanalíticas. Rev Lat Amer Psicop Fund [Internet]. 2007 [cited 2019 Apr 05];10(2):255-73. doi: 10.1590/1415-47142007002005

5. Campos ACV, Almeida MHM, Campos GV, Bogutchi TF. Prevalence of functional incapacity by gender in elderly people in Brazil: a systematic review with meta-analysis. Rev Bras Geriatr Gerontol. 2016;19(3):545-59. doi: 10.1590/1809-98232016019.150086

6. Pinto Jr EP, Silva IT, Vilela ABA, Casotti1CA, Pinto FJM, Silva MGC. Dependência funcional e fatores associados em idosos corresidentes. Cad Saúde Colet. 2016;24(4):404-12. doi: 10.1590/1414-462X201600040229

7. Galvão MTG, Bonfim DYG, Gir E, Carvalho CML, Almeida PC, Balsanelli ACS. Hope in HIV-positive women. Rev Esc Enferm USP. 2012;46(1):3844. doi: 10.1590/S0080-62342012000100005

8. Berlezi EM, Farias AM, Dallazen F, Oliveira KR, Pillatt AP, Fortes CK. Como está a capacidade funcional de idosos residentes em comunidades com taxa de envelhecimento populacional acelerado? Rev Bras Geriatr Gerontol. 2016;19(4):643-52. doi: $10.1590 / 1809-98232016019.150156$

9. Ministério da Saúde (BR). Secretaria de Atenção à Saúde. Departamento de Atenção Básica. Envelhecimento e saúde da pessoa [Internet]. 2006 [cited 2019 May 23]. Available from: http://bvsms.saude.gov.br/bvs/publicacoes/abcad19.pdf

10. Sartore AC, Grossi SAA. Escala de esperança de Herth - Instrumento adaptado e validado para a língua portuguesa. Rev Esc Enferm USP. 2008;42(2):227-32. doi: 10.1590/S0080-62342008000200003 
11. Hair JFJ, Black WC, Babin BJ, Anderson RE, Tatham RL. Multivariate Data Analysis. New Jerey: Pearson Education; 2010. 100 p.

12. Barbosa BR, Almeida JM; Barbosa, MR, Rossi-Barbosa, LAR. Avaliação da capacidade funcional dos idosos e fatores associados à incapacidade. Ciênc Saúde Coletiva. 2014;19(8):3317-25. doi: 10.1590/1413-81232014198.06322013

13. Lopes GL. Santos MIPO. Funcionalidade de idosos cadastrados em uma unidade da Estratégia Saúde da Família segundo categorias da Classificação Internacional de Funcionalidade. Rev Bras Geria Geront. 2015;18(1):71-83. doi: 10.1590/1809-9823.2015.14013

14. Cortez ACL, Menezes JMMM, Brandão PP, Silva GCB, Dantas EHM. Correlation among the Tests of Functional Capacity Evaluation of Elderly Participants of a Social Inclusion Project in the City of Teresina - Piauí. J Health Sci. 2019;20(4):277-82. doi: 10.17921/2447-8938.2018v20n $4 \mathrm{p} 277-282$

15. Almeida P, Mendonça MA, Marinho MS, Santos LS, Andrade SMB, Reis LA. Funcionalidade e fatores associados em idosos participantes de grupo de convivência. Rev Soba [Internet]. 2017 [cited 2019 Apr 15];18(1):53-64. Available from: http://www2.marilia.unesp.br/revistas/ index.php/sobama/article/view/7274

16. Dantas CMHL, Bello FA, Barreto KL, Lima LS. Capacidade funcional de idosos com doenças crônicas residentes em instituições de longa permanência. Rev Bras Enferm. 2013;66(6):914-20. doi: 10.1590/S0034-71672013000600016

17. Melo MFT, Silva HP. Chronic Diseases and Health's Social Determinants of Maroons Communities of Pará State, Amazon, Brazil. Rev ABPN [Internet]. 2015 [cited 2019 Apr 4];7(6):168-169. Available from: http://www.abpnrevista.org.br/revista/index.php/revistaabpn1/article/ view/103

18. Mantovani EP, Lucca SR, Neri AL. Associations between meanings of old age and subjective well-being indicated by satisfaction among the elderly. Rev Bras Geriatr Gerontol. 2016;19(2):203-22. doi: 10.1590/1809-98232016019.150041 